\title{
Otic Ointment Dosage Form
}

National Cancer Institute

\section{Source}

National Cancer Institute. Otic Ointment Dosage Form. NCI Thesaurus. Code $C 91175$.

An ointment intended for administration either on the outer ear or into the auditory

canal. 